\title{
Mempelajari Wilayah Perbatasan Sebagai Ruang Bersama
}

\section{Wahyuni Kartikasari}

Jurusan IImu Hubungan Internasional, Fakultas IImu Sosial dan IImu Politik, Universitas Muhammadiyah Yogyakarta

Ringroad Barat Tamantirto, Kasihan, Bantul 55183

Email: wahyunikartikasari@umy.ac.id

\begin{abstract}
Border problems are often originated from a very complex issue. Problems that arise are because of there is no uncertainty about the border, and disparity of boundary zone development between the country and neighboring countries. The latter problem often encourages the orientation and mobility of border communities who tend to prefer to more rapid development area. Problems can arise from the differences perception and outlook between the government and society about the meaning of border, as well. This paper proposed the concept of shared space as a strategic move to overcome that perceptual difference on the border. A space that is managed together both in planning and implementation, will be able to minimize the number of conflicts and tensions that often arise in the border region.

Keywords: border, shared space, border region, conflict.
\end{abstract}

\begin{abstract}
Abstrak
Masalah perbatasan seringkali disebabkan oleh isu yang kompleks. Masalah yang muncul dikarenakan tidak adanya kepastian tentang perbatasan, dan kesenjangan pembangunan zona batas antara negara dan negara-negara tetangga. Masalah yang belakangan muncul seringkali mendorong pada orientasi dan mobilitas komunitas batas yang cenderung ke arah perngembangan area yang lebih pesat. Permasalahan dapat muncul dari perbedaan persepsi dan pandangan luar antara pemerintah dan masyarakat mengenai makna dari batas. Artikel ini mengajukan konsep pembagian ruang sebagai langkah strategis untuk mengatasi perbedaan persepsi mengenai batas. Sebuah ruang yang dikelola bersama-sama baik dalam perencanaan dan pelaksanaan, hal ini akan mengurangi jumlah konflik dan ketegangan yang sering muncul di wilayah perbatasan.

Kata Kunci: perbatasan, pembagian ruang, batas wilayah, konflik
\end{abstract}

\section{PENDAHULUAN}

Definisi umum dari negara-bangsa adalah pemerintahan yang sah, adanya rakyat yang berdaulat dan memiliki wilayah tertentu dengan batas-batas yang jelas. Maka, proses untuk mengidentifikasi negara bangsa salah satunya dilakukan dengan cara mengenali batas-batas wilayahnya. Batas, menunjukkan tempat awal mula dan berakhirnya sesuatu, juga menandai kepemilikan atas sesuatu. Dalam tataran negara, batas wilayah merupakan persoalan kedaulatan negara, penanda kepemilikan suatu negara atas wilayah serta potensi-potensi yang berada di dalamnya. Pentingnya pengenalan wilayah ini, dapat terlacak dari Boundary Making Theory oleh Stephen B Jones (1945), yang mengungkapkan 3 tahap dari keseluruhan empat tahap pengelolaan perbatasan, yaitu Allocation, Delimitation, Demarcation, dan Administration.

Ditengarai ada persoalan yang timbul ketika memaknai perbatasan. Sering didapati, konflik perbatasan dipicu oleh persoalan-persoalan memaknai penentuan garis batas negara. Seperti beberapa kali 
terjadi adanya kasus penangkapan nelayan tradisional Indonesia oleh tentara laut negara Malaysia karena persoalan sederhana dimana para nelayan tersebut terbatas dalam peralatan navigasi, ataupun klaim suatu negara (atau lebih) atas wilayah tertentu karena belum jelas patok-patok batas wilayahnya.

Namun apakah melulu persoalan perbatasan timbul hanya antar pemerintah pada negara yang berbatasan saja? Mungkinkah, persoalan perbatasan itu juga sebenarnya dapat ditimbulkan oleh faktor-faktor di dalam negeri sendiri? Atau, mungkinkah persoalan tetap timbul, ketika batas wilayah yang jelas sebenarnya sudah ditetapkan?

Tulisan ini diimaksudkan sebagai pencarian alternatif pemecahan terhadap problem yang timbul di wilayah-wilayah perbatasan, terutama studi kasus-studi kasus di wilayah perbatasan Indonesia dengan beberapa negara tetangga. Mungkin saja terdapat perbedaan persepsi mengenai perbatasan baik oleh masing-masing negara, oleh pemerintah, ataupun oleh rakyat. Oleh sebab itu, sistematika pembahasan akan tersusun menjadi bagian pertama yang akan menilik, apa itu wilayah perbatasan maupun kawasan perbatasan, serta bagaimana proses pembentukan dan penetapannya. Dengan demikian, pada bagian ini diharapkan kita dapat memahami makna perbatasan bagi negara. Bagian kedua akan mengurai makna perbatasan bagi penduduk, terutama penduduk setempat yang langsung mengalami dan menerima dampak perbatasan ini. Samakah persepsi penduduk dengan makna perbatasan yang dimiliki negara? Bagian selanjutnya menunjukkan pada kita, ada problemproblem yang mungkin timbul akibat perbedaan pemahaman mengenai makna perbatasan baik itu bagi negara ataupun bagi penduduk, serta perbedaan kondisi di perbatasan. Bagian terakhir penulis mecoba menawarkan bentuk pengelolaan perbatasan dimana selanjutnya dapat ditelaah lebih jauh kemungkinan penerapannya.

\section{METODOLOGI}

PEMAHAMAN BATAS NEGARA BAGI NEGARA DAN CARA PENENTUANNYA

Pengenalan terhadap definisi perbatasaan dan istilah-istilah yang lazim dipakai, akan dapat membantu memetakan batas-batas hak-hak dan kewajiban-kewajiban negara serta arti penting daerah perbatasan.

Sebagaimana telah disebutkan secara sepintas di awal tulisan, penentuan perbatasan dapat merunut pada Boundary Making Theory oleh Stephen B Jones, yaitu Allocation, Delimitation, Demarcation, dan Administration.

Allocation/Alokasi: yang dimaksud dengan alokasi dalam teori ini adalah cakupan dari wilayah suatu negara, termasuk dimana wilayah yang berbatasan dengan negara tetangganya. Berkaitan dengan cakupan wilayah, Hukum Internasional mengatur cara-cara bagaimana sebuah negara memperoleh atau bahkan kehilangan wilayahnya. Untuk Indonesia, wilayah Indonesia adalah wilayah yang diwariskan dari penjajah Belanda. Hal ini sesuai dengan prinsip hukum internasional Uti Possidetis Juris yang menyatakan bahwa suatu negara mewarisi wilayah penguasa penjajahnya. Sebagai contoh, perjanjian perbatasan antara Kalimantan Barat dan Serawak yang menetapkan patok-patok wilayah perbatasan merunut batas-batas wilayah yang ditinggalkan oleh penjajah dahulu.

Delimitation/Penetapan Batas: Setelah cakupan wilayah diketahui, tahap berikutnya adalah mengidentifikasi wilayah-wilayah yang tumpang tindih ataupun wilayah yang masih harus ditentukan batasnya oleh negara.

Demarcation (Penegasan Batas): Demarkasi atau penegasan batas merupakan tahap yang ditempuh setelah penetapan batas atau delimitasi yang biasanya ditetapkan melalui perjanjian batas. Penegasan Batas dilakukan di lapangan secara fisik. Ketegasan ini diperlukan karena sifat garis batas yang sangat penting, yaitu sebagai tanda awal mula dan berakhirnya hak, kewajiban serta kedaulatan negara. Penegasan batas dilakukan dengan menandai perbatasan dengan memasang tanda-tanda atau patok-patok batas di 
sepanjang garis perbatasan sesuai dengan perjanjian.

Administration/ manajemen pembangunan.

Walaupun tahap ini merupakan tahap terakhir, bukan berarti tahap administrasi hanya dapat dilakukan setelah tahap 3 yaitu penegasan batas, dilaksanakan.

Dalam Theory of Boundary Making, pengelolaan wilayah perbatasan yang baik dapat saja menumpang-tindihkan atau menjalankan secara bersamaan proses

pembangunan perbatasan dan demarkasi. Hal ini dapat dimengerti karena, proses penyelesaian masalah dan pembangunan bidang-bidang ekonomi, sosial, budaya dan politik memerlukan waktu yang panjang. Selain itu diperlukan pula sosialisasi pemahaman bagi penduduk di kawasan perbatasan, bahwa setelah penegasan batas ditentukan, mereka dapat terpisah secara administratif kenegaraan dengan sanak keluarga dan kerabat yang berlainan warganegara. Dalam tahap ini pula, seluruh aspek pemerintahan dalam negeri termasuk didalamnya. Pemerintahan Daerah dapat terlibat secara aktif dalam pengelolaan perbatasan.

Lalu bagaimana pemerintah Indonesia memandang daerah perbatasan? Sebagai Negara kepulauan (archipelagic state), berdasarkan hukum internasional Negara Kesatuan Republik Indonesia (NKRI) memiliki beraneka perbatasan nasional baik berupa perbatasan wilayah dengan kedaulatan penuh maupun perbatasan kawasan dengan hak-hak pemanfaatan sumber daya alam tertentu (misal landas kontinen dan Zona Ekonomi Eksklusif). Archipelagic state principle merupakan pengejawantahan Wawasan Nusantara yang memandang wilayah laut bukan sebagai pemisah, tetapi justru sebagai penghubung dengan wilayah darat di seluruh wilayah NKRI. Berdasarkan prinsip ini wilayah laut Indonesia yang pada masa penjajahan Belanda hanya seluas $100.000 \mathrm{~km}^{2}$ menjadi kira-kira $3.000 .000 \mathrm{~km}^{2}$. Wilayah Laut NKRI dengan kedaulatan penuh tersebut terdiri dari Perairan Pedalaman, Perairan Kepulauan atau Perairan Nusantara, dan Laut Teritorial/Laut Wilayah.

Dalam Pengaturan Dalam Bidang Keamanan di Daerah-daerah Perbatasan Antara Pemerintah Republik Indonesia dan Pemerintah Malaysia Pasal I ayat e, Yogyakarta, 3 Desember 1984, mengungkap definisi- definisi perbatasan sebagai berikut: Daerah Perbatasan adalah daerah daratan, laut dan udara diatasnya sepanjang perbatasan bersama kedua negara, yang batas luas daerahnya disesuaikan dengan kebutuhan dan persetujuan kedua negara. Terdapat pula istilah Kawasan Penyangga Perbatasan yang dimaksudkan untuk memudahkan pengawasan terhadap arus barang dan manusia yang keluar masuk Indonesia, untuk kepentingan pertahanan keamanan nasional.

Untuk menentukan batas laut kedua negara, maka ada dua konsep yang digunakan: yaitu konsep Teritorial Laut dan Zona Ekonomi Eksklusif (Juda, 1996). Ini adalah perangkat aturan yang disepakati melalui Konvensi Hukum Laut 1982, yaitu adanya Konsep Laut Territorial dan Zona Ekonomi Eksklusif (ZEE) sejauh 200mil dari garis dasar yang dipakai untuk menentukan batas laut teritorial suatu negara (Rais,2006). Alasan untuk penggunaan dua konsep ini adalah:

While the oceans cover some 71 percent of the earth's surface, the human use of the ocean is extremely concentrated, with by far the majority of activities occuring in area close to the coast ( $\max 12$ miles).

Second, while ocean extend over vast areas, the resources which the contain or cover are not evenly distributed. The connectioin between the presenceof fisheries and continental shelf areas of the world has long been noted. According to UNFAO some $95 \%$ of the world fish catch comes from areas within 200 miles of the coast.

Dari dua pernyataan di atas, maka model atau potensi konflik dalam wilayah Laut Teritorial akan berbeda dengan konflik di ZEE. Konflik dalam wilayah laut teritorial adalah konflik penggunaan ruang laut (conflict in the use of ocean shore). Sehingga dalam wilayah ini diperlukan administrasi lautan yang tertib (ocean administration) dan menerapkan kadaster laut. Konflik di ZEE adalah konflik atas pemanfaatan sumber daya perikanan (misalnya pencurian). Sehingga, negara-negara yang dititipi ZEE harus menetapkan zona-zona perikanan dan jumlah tangkapan yang diperbolehkan (total allowable catch). Azas kadaster tidak dapat ditetapkan disini, dimana adminstrasi 
lautan lebih sederhana, namun pengawasan harus lebih ketat.

Untuk wilayah laut, ada beberapa yang lain menambahkan dengan Wilayah laut Zone Tambahan (Raharjo dalam Kaligis,2003), yaitu nilai strategis batas wilayah laut dengan Zone Tambahan selebar 12 mil laut yang mengelilingi laut wilayah selebar 12 mil laut. Untuk wilayah laut dengan Zone Tambahan selebar 12 mil laut, membuat Indonesia dapat melaksanakan pengawasan atas masalah-masalah bea-cukai, fiskal, imigrasi atau kesehatan (Raharjo dalam Kaligis,2003).

Selain Laut Teritorial, ZEE dan Zona Tambahan, Rudolf Matindas menambahkan dengan Zona Perikanan dan Landas Kontinen (Matindas dalam Kaligis,2003:88). Zona perikanan tidak sama dengan ZEE walaupun perkembangan menunjukkan bahwa semakin banyak negara mengacu kepada ZEE. Fishery Zone umumnya hanya mengacu pada sumber daya hayati ikan yang ada dalam water colum-nya ${ }^{1}$. Landas Kontinen (Continental Shelf) adalah dasar laut dan tanah dibawahnya (sea-bed and subsoil) yang berbatasan dengan daerah dasar laut dibawah laut teritorial, sampai dengan batas maksimal 350 mil dari garis pangkal, atau 100 mil dari kedalaman 2.500 meter. Di Landas Kontinen negara memiliki hak-hak berdaulat untuk memanfaatkan dan mengelola sumber daya alamnya (Agoes dalam Kaligis, 2003:67). Menurut UU No.1 Th 1973 tentang Landas Kontinen Indonesia: adalah dasar laut dan tanah dibawahnya di luar perairan Republik Indonesia sampai dengan kedalaman 200meter atau lebih (Agoes dalam Kaligis, 2003:69).

Batas suatu negara di laut kemudian ditetapkan dengan menarik Garis-garis Pangkal atau Base Line yang menghubungkan rangkaian titik-titik terluar yang disebut Titik Dasar atau Base Point. Titik-titik dasar ini ditentukan melalui survey hidrografi oleh Dinas Hidro-Oseanografi TNI AL (Sondakh dalam Kaligis, 2003:83).

Apabila ditinjau secara fisik, Indonesia merupakan negara terbesar kelima didunia yang dibatasi oleh dua matra, yaitu di laut dengan sepuluh negara: Australia, Malaysia, Singapura, India, thailand,Vietnam, Filipina,
Palau, Papua New Guinea dan Timor Leste; dan di darat dengan tiga negara: Malaysia, Papua New Guinea dan Timor Leste.

Dalam Kamus Besar Bahasa Indonesia (1999, hal 98) menyebutkan perbatasan merupakan perwujudan dari kedaulatan teritorial, sehingga daerah perbatasan dimaknai pula sebagai daerah atau jalur pemisah antara unit-unit politik (negara). Pemisahan ini dapat terlihat jelas dalam bentuk fisik seperti Tembok China, Tembok Berlin, Tembok Jerusalem, Tembok Israel, dan lain-lain. Pemisahan fisik kemudian jelas memperlihatkan kepemilikan negara atas suatu wilayah, beserta segenap isi yang berada didalamnya seperti kekayaan alam, bangunan, dan masyarakat.

Kepentingan kepemilikan ini, atas dasar kedaulatan, seringkali menimbulkan konflik. Konflik di perbatasan Thailand - Kamboja atas kepemilikan Kuil Phreah Vear, konflik klaim wilayah Sipadan - Ligitan antara Indonesia dan Malaysia. Khusus bagi Indonesia, berbagai studi ${ }^{2}$ menunjukkan bahwa isu atau masalah perbatasan sangat kompleks. Secara umum permasalahan-permasalahan di perbatasan dapat diidentifikasi berdasar beberapa kelompok isu berikut:

Isu geografis-teritorial karena belum disepakatinya batas-batas wilayah darat maupun laut di beberapa tapal batas dengan negara tetangga. Antara Indonesia dan Singapura, masih ada perbedaan persepsi tentang batas wilayah laut di selat Malaka dan Pulau Nipah. Antara Indonesia dan Malaysia, batas laut teritorial Malaysia di bagian utara selat malaka dan di selat Singapura belum menghasilkan kesepakatan Batas Landas Kontinen di laut China Selatan, Batas laut teritorial dan landas kontinen sebelah timur Pulau sebatik. Penarikan batas menurut pulau terluar, tidak sesuai dengan status Malaysia yang bukan negara kepulauan. Antara Indonesia dan Filipina, terdapat perbedaan persepsi antara batas ZEE dan landas kontinen. Antara Indonesia dan Vietnam, ada perbedaan persepsi dalam penentuan batas wilayah di sekitar Kepulauan Natuna. Penarikan batas menurut pulau terluar, tidak sesuai dengan status Vietnam yang bukan negara kepulauan. Antara Indonesia dan Republik Rakyat Cina, terjadi tumpang tindih wilayah 
perairan ZEE dengan klaim pihak RRC. Antara Indonesia dan Palau, posisi kepulauan Palau berada di selatan Samudra Pasifik berbatasan dengan Papua, tepatnya di P.P. Asia dan P.P Mapia (milik Indonesia). Disini penetapan ZEE belum dapat dilaksanakan, sehinga kedua negara masih dihadapkan pada masalah nelayan tradisional. Antara Indonesia dan Australia, bahwa dengan terpisahnya Timor-Timur (Timor Leste) dari wilayah Indonesia, penetapan Batas Wilayah Laut di celah Timor (Timor Gap) perlu dirundingkan kembali. Belum ada kesepakatan bagi Batas Landas Kontinen di sekitar perairan P Christmas, begitu juga tentang status Karang Ashmore. Belum tuntasnya penataan batas negara di Kabupaten Belu-Timor Leste. Sektor Timur (Kab Belu) sepanjang 149,1km; sektor barat Kab Timor Tengah Utara 109km dan Kupang 10,7 km berbatasan dengan Enclave Oecusse. Pilar batas yang permanen baru sebagian kecil ada. Dari keseluruhan perbatasan negara sepanjang 268,8km kedua negara dalam provisional agreement telah berhasil menyepakati 907 koordinat titik-titik batas atau sekitar 96\% dari total panjang garis batas, dan telah dibangun 47 tugu/pilar demarkasi di kab Belu-Timor Leste.

Isu-isu keamanan dan kedaulatan nasional, terutama kejahatan lintas batas (cross border crimes) yang teroganisir seperti penyelundupan, perdagangan illegal (obat, manusia, bahan-bahan makanan, kayu, dll) dan garis batas (dispute area) yang tidak jelas dengan akibat berkurangnya wilayah nasional Indonesia.

Isu lingkungan yakni kerusakan ekologi dan eksploitasi sumber daya berlebihan, bersifat lintas batas dan dilakukan secara legal maupun ilegal. Contoh: Illegal loging. Potensi sumber daya alam yang melimpah belum mampu memberikan nilai tambah yang besar. Serta pusat pelestarian lingkungan yang belum berkembang.

Isu kemiskinan, keterbelakangan, keterbatasan prasarana ekonomi, pendidikan dan kesehatan yang dialami warga negara Indonesia di perbatasan, memicu terjadinya perdagangan manusia (human trafficking). Sarana transportasi dan pembangunan yang masih minim dan infrastruktur yang terbatas.
Isu koordinasi dan implementasi kebijakan pembangunan akibat jauhnya jarak komunikasi antar pemerintah lokal dan pemerintah daerah atau pusat. Rendahnya alokasi pembiayaan pembangunan atau ketergantungan pada pemerintah pusat dan belum terwujudnya keterpaduan dalam upaya pengelolaan perbatasan. Pembangunan hanya diarahkan pada pusatpusat kota/pertumbuhan, juga masih minimnya pelayanan CIQS (Custom-Immigration-Quarantine-Service) pada pintu-pintu lintas batas.

Isu kependudukan dan perubahan sosial terutama akibat migrasi lintas batas yang bersifat legal dan illegal. Pengungsi yang sekarang dikenal sebagai warga baru keturunan Timor Leste (eks pengungsi), terpisah dengan sanak saudaranya yang berada di Timor Leste. Kekerabatan penduduk perbatasan dan Hak Ulayat di Kabupaten Belu yang secara sosiologis tidak mengenal batas wilayah negara, memerlukan pendekatan dan upaya persuasif dalam melaksanakan penegakan kedaulatan Negara. Untuk keperluan Lintas Batas, Pemerintah Timor Leste belum menerapkan Pas Lintas Batas (PLB). Sedangkan di Papua, mulai tahun 2008 pemerintah PNG membatasai penggunaan Kartu Pelintas Batas (KLB) karena banyak disalahgunakan.

Isu patriotisme dan ketahanan nasional terutama menyangkut persepsi penduduk perbatasan bahwa mereka dianaktirikan.

\section{HASIL DAN PEMBAHASAN}

\section{PEMAHAMAN BATAS NEGARA BAGI PENDUDUK}

Setelah memahami pandangan negara mengenai konsep perbatasan, timbul pertanyaan, apakah makna pemisahan tersebut benar-benar dapat berlaku? Bagaimanakah konsep perbatasan yang dipahami oleh masyarakat daerah perbatasan, sebagai masyarakat yang langsung terlibat nyata dengan persoalan-persoalan perbatasan? Jalan apa yang dapat ditempuh untuk memadukan konsep perbatasan oleh negara dengan konsep wilayah perbatasan bagi masyarakat setempat? Pertanyaan ini muncul karena menilik beberapa kondisi di daerah perbatasan yang ada antara Indonesia dengan negara-negara tetangga sebagai berikut:

Perihal kondisi masyarakat terutama di daerah 
perbatasan darat, sebagian besar penduduk di daerah perbatasan merupakan masyarakat serumpun. Ini dapat terlihat misalnya dari komposisi etnis yang relatif sama di perbatasan Kalimantan Barat (antara lain Dayak, Melayu, Cina) dan Sarawak (Iban, Cina, Melayu, Bidayuh, Melanau, dan lain-lain) (Akil dalam Florus, 1994:186 ; Kartikasari, 1997: 26-27).

Sedangkan pada daerah perbatasan antara kabupaten Belu dan Timor Leste, seluruh suku-suku di daratan Timor adalah satu keturunan dengan empat keluarga besar yaitu Silah Liurae (Lorosae), Dong Silah (Ambeno), Ampoang Silah (Ampoang) dan Sonbae Silah (Soe-Belu) Wuryandari ${ }^{3}$.

Hubungan kekerabatan yang masih erat ini membuat penduduk daerah perbatasan selalu berkomunikasi dan berhubungan dengan keluarganya walaupun sanak keluarga tersebut tinggal di negara tetangga. Sehingga kegiatan penduduk melintas perbatasan adalah kegiatan lumrah sehari-hari seperti kunjungan keluarga, aktifitas sosial dan kebudayaan serta pemenuhan kebutuhan ekonomi. Daerah Perbatasan menjadi daerah aktivitas untuk memenuhi kebutuhan hidup. Di daerah perbatasan Papua, akibat pembagian garis batas antara Inggris dan Belanda pada 16 Mei 1895 melalui The Hague Treaty, banyak warga masyarakat perbatasan Indonesia memiliki tanah ulayat berupa lahan garapan yang berada di wilayah Papua New Guinea (PNG), dan demikian pula sebaliknya.

\section{PERBEDAAN KONDISI DI KEDUA WILAYAH NEGARA MEMICU PROBLEM DAN KONFLIK}

Selain telah diungkapkan di bagian-bagian awal tulisan, dimana terjadi beragam konflik dari beragam isu menyangkut daerah perbatasan, bagian ini khusus ingin menelaah problem yang timbul di perbatasan khusus pada amatan kondisi pembangunan di daerah perbatasan.

Perbedaan kondisi antara kedua wilayah yang berbatasan, akan menjadi magnet migrasi dari daerah yang satu ke daerah lain. Kita tidak dapat mengesampingkan kenyataan bahwa, ternyata didaerah perbatasan-perbatasan Indonesia dengan Malaysia terdapat perbedaan tingkat pembangunan yang relatif mencolok. Sarana dan prasarana kehidupan di kotakota kecil di Malaysia relatif lebih baik dan tersedia lengkap dibandingkan dengan kota-kota kecil yang ada di wilayah Indonesia.

Perbedaan tingkat kesejahteraan ekonomi yang ada di daerah perbatasan antara Kalimantan dengan Malaysia membuat kasus-kasus trafficking banyak terjadi. Penduduk di wilayah perbatasan Kalimantan Barat dan Kalimantan Timur banyak tergiur untuk menjadi tenaga kerja di Sarawak, bahkan dengan status tenaga kerja ilegal sekalipun. Kalimantan Barat menempati urutan besar dalam kasus trafficking, bersama-sama dengan Batam.

Selain kasus trafficking yang terjadi akibat dari adanya perbedaan tingkat kesejahteraan ekonomi yang ada di daerah perbatasan Kalimantan sebagaimana telah dijelaskan diatas, persoalan orientasi penduduk yang lebih besar pada negara tetangga menimbulkan kekhawatiran tersendiri bagi pemerintah untuk alasan loyalitas dan nasionalisme. Terutama sekali karena jarak ibu kota yang jauh, suplai barang-barang dari Pontianak menyebabkan harga-harga barang di wilayah pedalaman menjadi mahal, sehingga masyarakat lebih mengandalkan pasokan barang dari Sarawak yang lebih dekat, lebih mudah diperoleh dan lebih murah. Hijrahnya ratusan pedagang ke Sarawak juga membuktikan perekonomian di daerah perbatasan sangat tergantung pada Sarawak. Kegiatan perdagangan ke Sarawak ternyata memberikan kontribusi besar bagi pertumbuhan ekonomi negara tetangga tersebut.

Bahkan menjadi hal yang lazim bagi penduduk Indonesia di daerah perbatasan untuk menggunakan mata uang Ringgit Malaysia selain mata uang Rupiah Indonesia.

Di sektor kehutanan, produksi kayu yang sebenarnya mereka dapatkan dari Kalimantan Barat, menjadikan negara Malaysia Timur menjadi salah satu daerah penghasil devisa terbesar kedua setelah minyak dan gas (Kartikasari, 2005: 8-9). Kasus-kasus illegal logging terjadi karena kondisi infrastruktur yang lebih baik di wilayah Sarawak memungkinkan mereka dapat mengakses hutan-hutan perbatasan dari wilayah Sarawak dan segera pergi ketika terjadi razia. Hal ini 
dimungkinkan karena kondisi jalan yang relatif baik sudah terbangun di wilayah Sarawak memudahkan mobilisasi.

Kondisi pembangunan yang lebih maju dan fasilitas umum yang lebih lengkap di Sarawak membuat penduduk lebih sering dan lebih mudah memanfaatkan fasilitas hidup di Sarawak. Penduduk Kalimantan Barat akan lebih mudah memanfaatkan sarana dan prasarana umum seperti jalan, pasar, rumah sakit, sekolah, di Sarawak dibandingkan jika mereka harus pergi ke Pontianak.

Untuk persoalan orientasi kehidupan dan nasionalisme juga terdapat beberapa masalah. Kita pernah mendengar beberapa berita sekitar perekrutan warganegara Indonesia menjadi tentara atau laskar di Malaysia. "Perekrutan" warga Indonesia menjadi bala bantuan Malaysia sebenarnya sudah terjadi sejak perseteruan Indonesia - Malaysia pada tahun 1960-an. Perbatasan Kalimantan dan Malaysia merupakan kawasan konflik saat Soekarno melancarkan konfrontasi mengganyang Malaysia. Ribuan pasukan reguler dan paramiliter dikerahkan untuk menyokong politik konfrontasi itu.

Sebagian dari warganegara Indonesia menjadi tentara cadangan negara Malaysia untuk mencari nafkah. Sebagian lain sengaja disusupkan tentara Indonesia untuk menjadi mata-mata (Kompas, 2008). Beberapa sumber menyebutkan, anggota keluarga mereka menjadi anggota Askar, malah menjadi Tentara Diraja Malaysia dan sudah menjadi warga Malaysia. Yakon Lomon, Temenggung Agung Dewan Adat Dayak wilayah perbatasan, mengatakan, Malaysia telah merekrut warga Indonesia menjadi laskar sejak 1962. Para pemuda Dayak berbondong-bondong menjadi anggota Tentara Nasional Kalimantan Utara, dan dengan demikian menjadi warga negara Malaysia. Karena buruknya administrasi saat itu, mereka tak juga melepas status kewarganegaraan Indonesia. Kini, kata Yakon, masih banyak putra Dayak beralih kewarganegaraan. Awalnya, mereka bekerja untuk pengusaha-pengusaha Malaysia yang membuka hutan di perbatasan. Saat pekerjaan usai dan para pemuda itu menganggur, tawaran menjadi askar (Askar
Wataniah) datang. Askar Wataniah adalah komponen cadangan tentara Malaysia. Pasukan ini dibentuk untuk menjalankan konsep "pertahanan menyeluruh”, yang mengatur adanya Angkatan Tetap dan Angkatan Simpanan. Pasukan ini bertugas membantu tentara reguler di masa perang atau menangani bencana. Ada beberapa bagian pasukan ini, antara lain elemen tempur, elemen bantuan tempur, elemen ahli, dan pasukan kerahan. Askar acap kali pula dipakai para pengusaha Malaysia untuk menjaga aset-aset mereka.

Hal yang relatif umum pula bagi masyarakat di perbatasan adalah, walaupun mereka warganegara Indonesia, tapi mereka juga juga memiliki kartu identitas Malaysia. Bagi orang yang tinggal di perbatasan hal ini sangat memungkinkan, sebab mereka pada dasarnya berasal dari suku yang sama yaitu Dayak Bidayuh.

Pulau Sebatik sebagai pulau terluar Republik Indonesia mempunyai fenomena tersendiri pula. Secara administratif pulau ini terletak di dua negara, di bagian utara dikelola oleh negara bagian Sabah, di Malaysia sedangkan di bagian selatan dikelola oleh propinsi Kalimantan Timur, Indonesia. Pada masa dahulu, Pulau Sebatik pernah menjadi tempat pertempuran hebat antara pasukan Indonesia dan Malaysia. Kondisi sarana dan prasarana pulau ini sungguh memprihatinkan. Fasilitas jalan di pulau ini adalah tanah tidak beraspal, becek dan licin.

Ketersediaan jaringan listrik sangat minim, sehingga sangat sulit untuk memperoleh fasilitas listrik bagi industri besar di sini.

Kota Tawau Malaysia yang terletak di seberang utara, sangat terlihat jelas dari Pulau Sebatik. Kota Tawau relatif lebih jauh maju dan berkembang pesat secara ekonomi dibandingkan Pulau Sebatik. Kondisi ini menyebabkan masyarakat Sebatik sangat tergantung pada kota Tawau. Masyarakat nelayan Sebatik dapat menjual ikan hasil tangkapannya di tempat pelelangan ikan di Tawau. Kapal-kapal merekapun dilengkapi dengan bendera Malaysia agar mudah melakukan transaksi dan melintas batas, karena di Sebatik tidak ada pabrik es yang dapat mengawetkan ikan-ikan mereka. Ikan-ikan hasil tangkapan nelayan Sebatik ini 
oleh pengusaha Malaysia diberi merek Malaysia dan diekspor ke negara lain dengan harga sampai 3-4 kali lipat. Untuk contoh yang lain, ketika rakyat di daerah lain di Indonesia, sedang kesusahan membeli minyak goreng atau susu yang harganya terus melambung, hal ini tidak berlaku bagi masyarakat Sebatik. Mereka dapat memperoleh keperluan sehari-harinya melalui Malaysia, dimana mereka mendapatkan barang-barang mewah di Indonesia itu dengan harga murah di Malaysia. Harga murah ini terjadi karena barang-barang kebutuhan pokok di subsidi oleh pemerintah Malaysia. Untuk akses informasi dan berita, masyarakat Sebatik lebih sering dan mudah mengakses acara-acara dari televisi Malaysia dibandingkan dengan televisi Indonesia, karena di daerah ini tidak ada satupun saluran televisi yang bisa ditangkap dengan jelas.

Problem-problem perbatasan di Indonesia ternyata tidak hanya terjadi jika kondisi wilayah Indonesia yang lebih tertinggal dibandingkan dengan negara tetangga. Di perbatasan wilayah Indonesia dan Papua New Guinea, dapat dikatakan kondisi Indonesia relatif lebih baik, namun ternyata tetap saja menyisakan masalah.

Konsulat Republik Indonesia saat ini tengah menangani masalah repatriasi warga negara Indonesia yang masuk ke wilayah Papua New Guinea pada tahun 1970-an yang jumlahnya mencapai ribuan, sama halnya dengan ribuan warga Papua New Guinea yang tinggal di wilayah Papua. Status mereka tidak jelas dan tidak diakui pemerintah mereka masing-masing. Akibatnya mereka tidak dapat menikmati pelayanan fasilitas publik seperti kesehatan dan pendidikan (Kompas, 21 Desember 2008) di daerah tempat tinggal mereka, di daerah perbatasan.

Menilik paparan diatas, maka konsep perbatasan yang sejatinya berupa batas, memisahkan masyarakat perbatasan berdasarkan status warganegara yang berbeda, menjadi kabur. Masyarakat memperlakukan dan memerlukan wilayah perbatasan sebagai ruang aktivitasnya sehari-hari, tanpa ada batasan dan peraturan. Batasan akan akses terhadapa sarana dan prasarana kehidupan berlandaskan hak dan kewajiban sebagai warganegara.

\section{PENYELESAIAN MASALAH MELALUI RUANG BERSAMA}

Dari dua bagian di atas, sedikit kesimpulan yang bisa ditarik adalah, negara menjadikan perbatasan sebagai isolasi interaksi komunitas dan kegiatannya dari komunitas dan kegiatan negara di seberangnya. Dari beberapa kasus di perbatasan yang telah dikemukakan diatas, sering menimbulkan polemik. Negara khawatir jika terlalu sering dan banyaknya masyarakat mengandalkan sarana dan prasarana yang ada di negara tetangga, kehidupan mereka akan lebih cenderung berorientasi kepada negara tetangga, sehingga apada akhirnya akan melunturkan kecintaan warganegara kepada tanah air.

Di pihak rakyat, nilai perbatasan yang sejatinya membatasi mereka, menjadi kabur. Karena kepentingan ekonomi sehari-hari, kegiatan sosial kemasyarakatan dan pemenuhan keperluan hidup adalah prioritas utama mereka. Dengan konteks ini, daerah perbatasan tidak dapat semerta-merta dipahami sebagai batas pemisah negara (state borders).

Lalu, dapatkah dua pemahaman yang berbeda ini dipertemukan?

Diperlukan pemahaman yang lebih luas pada kondisi yang ada di wilayah dengan menimbang karakteristik kehidupan masyarakat yang ada didalamnya, yang mungkin saja dapat bergeser dari definisi perbatasan oleh negara. Wilayah perbatasan dapat dilihat sebagai pemukiman (urban settlements) yang berlokasi di wilayah batas.

Ketika wilayah perbatasan sebenarnya adalah kota pemukiman, seperti kota-kota pemukiman lainnya di luar wilayah perbatasan, maka akan terlihat adanya interaksi sosial, politik, ekonomi, etnik, dan lain-lain dalam kehidupan sehari-hari dalam satu ruang publik. Tanpa memandang batasan warganegara, tapi yang ada adalah satu ikatan etnis, ataupun ikatan kekeluargaan serta ikatan kepentingan kehidupan sehari-hari. Mengenali wilayah perbatasan dari sudut ini adalah mempelajari dan mengenali persoalan sosial, ekonomi, politik, etnis, agama, dan lain-lain dalam suatu ruang kota kehidupan dengan segala fasilitas kelengkapannya seperti pasar, stasiun, jalan, taman, rumah sakit dan lain-lain. Ruang bersama ini merupakan ruang untuk 
saling berinteraksi untuk kehidupan bersama, memenuhi kebutuhan hidup secara besama-sama.

Sebenarnya, jika kita dapat menilik sejenak hal-hal mengenai kerjasama ruang antar negara, pengelolaan ruang bersama antar negara telah dilakukan dalam bentuk lain, dalam berbagai contoh berikut.

Pertama, Timor Gap. Timor Gap atau disebut juga dengan celah Timor adalah daerah landas kontinen yang terletak antara Timor Leste dan Australia. Pada masa sewaktu Timor Leste masih menjadi salah satu propinsi di Indonesia, telah tercapai kerjasama antara Indonesia dan Australia untuk eksplorasi minyak dan gas di wilayah ini. Pada tahun 1972, Indonesia dan Australia menandatangani kesepakatan untuk batas dasar laut Timor, dimana kemudian ditetapkan bagian barat laut Arafura dan sebelah selatan Kepulauan Tanimbar. Perjanjian ini memperpanjang garis batas yang sebelumnya telah ditetapkan pada tahun 1971 (Warsito, 2008: 73-74). Timor Gap menjadi wilayah yang strategis karena kandungan minyak bumi dan gas alamnya. Celah Timor merupakan salah satu dari enam kawasan yang memiliki cadangan minyak tergolong besar selain Timor Leste wilayah tengah, Venezuela, Mexico, Argentina dan Madagaskar. Cadangan minyak yang dikandung Celah Timor diperkirakan sekitar 5 milliar barrel dan endapan gas sekitar 50 miliar kaki kubik (Warsito, 2008: 76-78).

Kedua, Elang Kakatua. Ladang minyak ini relatif berukuran kecil, dieksplorasi oleh perusahaan perminyakan Conoco Philips. Ketika Timor Leste masih menjadi bagian dari Indonesia, pendapatan 50 juta Dollar AS yang dihasilkan dari ladang minyak ini dibagi antara Indonesia dan Australia. Setelah merdeka, Timor Leste menggantikan Indonesia dalam perolehan bagian tersebut.

Ketiga, Bayu Undan. Ladang yang juga di kelola oleh Conoco Phillips ini kaya akan cairan gas alam. Sejak mulai di produksi pada tahun 2004 dengan target pengembangan 20 tahun kedepan, Timor Leste diharapkan dapat memperoleh 1,8 milliar dollar AS.

Keempat, Greater Sunrise. Kandungan gas di Greater Sunrise ini dua kali lipat dibandingkan denga yang ada di Bayu Undan. Dua puluh persen luas wilayah ladang ini berada dalam Wilayah Pengembangan Minyak Bersama, sedangkan sisanya yang 80\%dikuasai Australia, walaupun di klaim pula oleh Timor Leste.

Kelima, Laminaria-Corralina. Wilayah ladang minyak yang di eksplorasi oleh Woddside ini terletak diluar Wilayah Pengembangan Minyak Bersama, tapi letaknya lebih dekat ke wilayah Timor Leste. Wilayah ini diklaim baik oleh Timopr Leste, juga Australia.

Keenam, Kawasan Berikat. Kawasan berikat adalah suatu bangunan, tempat atau kawasan dengan batasbatas tertentu yang didalamnya dilakukan kegiatan usaha industri pengolahan barang dan bahan, kegiatan rancang bangun, perekayasaan, penyortiran, pemeriksaan awal, pemeriksaan akhir, dan pengepakan atas barang dan bahan asal impor atau barang dan bahan dari dalam Daerah Pabean Indonesia Lainnya (DPIL), yang hasilknya terutama untuk tujuan ekspor. Walaupun buka suatu daerah pengelolaan bersama, ataupun belum tentu terletak di kawasan perbatasan, melalui contoh ini yang akan diutarakan adalah bentuk perlakuan khusus yang diterapkan pada wilayah ini. Yang memungkinkan beberapa pembebasan bersyarat terhadap kegiatan memasukkan dan mengeluarkan barang. Termasuk pula ke dalam golongan ini adalah Kawasan Pabean. Kawasan Pabean adalah kawasan dengan batas-batas tertentu di pelabuhan laut, bandar udara atau tempat lain yang ditetapkan untuk lalu-lintas barang yang sepenuhnya berada di bawah pengawasan Direktorat Jenderal Bea dan Cukai

Beberapa contoh diatas mengemukakan bahwa pengelolaan-pengelolaan ini lebih bersifat ekonomi, karena kita melihat secara langsung manfaat ekonomi dengan perolehan devisa negara yang besar yang didatangkan dari model pengelolaan seperti ini. Sumber alam minyak sampai masa sekarang merupakan satu-satunya sumber pembangkit tenaga untuk berbagai proses produksi dan konsumsi kegiatan manusia. Ketersediaan minyak dan keseimbangan energi serta distribusinya yang tidak merata di dunia, membuat minyak tampil sebagai salah satu komoditi yang sangat penting dan strategis secara ekonomi dan 
politik. Minyak dapat terkait dengan beberapa hal penting seperti tingkat inflasi, pertumbuhan ekonomi, pengangguran, orientasi kebijakan politik luar negeri dan perdagangan, pada suatu negara. Akibatnya, seluruh hal yang berkaitan dengan minyak dan gas akan menempati priorotas utama dalam hal-hal tersebut, baik itu bagi negara pengimpor maupun pengekspor.

Melalui sedikit contoh diatas, sebenarnya kita telah mempunyai pengalaman terhadap pengelolaan ruang bersama, dan relatif dapat dikatakan bahwa bentuk pengelolaan seperti ini mudah dilaksanakan, karena ada kepentingan ekonomi didalamnya. Pertanyaan berikutnya, dapatkah model pengelolaan ini diterapkan di bidang sosial dan budaya?

Pada bagian terakhir tulisan ini, mencoba mengemukakan pengelolaan ruang bersama yang memprioritaskan eksplorasi sumberdaya alam ataupun kegiatan ekonomi seperti contoh diatas, lalu ditransfer dalam bentuk pengelolaan bersama ruang untuk interaksi sosial dan budaya, selain tentu saja, bidang ekonomi pula. Kawasan yang dapat dikembangkan untuk Ruang bersama ini adalah Kawasan Perbatasan, atau bahkan mungkin Kawasan Penyangga Perbatasan. Kawasan yang telah ditetapkan secara jelas batas-batas wilayahnya, namun penduduk antar negara masih dapat saling berinteraksi, dan saling memanfaatkan kondisi kota yang relatif baik.

Pengembangan kawasan duty free zone pada perbatasan Malaysia dan Thailand di Bukit Kayu Hitam, dapat dijadikan ide awal. Disini tersedia suatu kawasan yang relatif besar, dimana semua orang dapat mengkases wilayah ini untuk berbelanja. Konsep seperti ini bisa saja kenudian dikembangkan menjadi suatu kota kecil yang dilengkapi dengan sarana dan prasarana seperti rumahsakit, sekolah, dan lain-lain. Dan dapat diperlebar menjadi kawasan pemukiman bagi para komuter yang bekerja di negara tetangga, sehingga membuat warganegara tidak perlu berdiam di negara tetangga.

Pemahaman ruang bersama ini diharapkan membantu mempercepat proses pengelolaan perbatasan pada tahapan keempat dalam Boundary Making Theory, yaitu tahapan administrasi. Kesadaran dan kerjasama kedua negara yang berbatasan sangat diperlukan. Hal ini dapat dimengerti karena untuk mengelola pembangunan, akan melibatkan multisektor dan perencanaan yang terintegrasi dari bidang-bidang seperti politik, pertahanan, keamanan, sosial, ekonomi, budaya, hukum, lingkungan hidup, sarana dan prasarana dan lain-lain. Pada tahap ini pula terjadi kerjasama bagi pembangunan wilayah perbatasan antara kedua negara untuk bidang-bidang tersebut diatas. Dan sekali lagi, pada tahap ini lingkaran pekerjaan sangatlah besar. Seluruh aspek pembangunan dan pemerintahan terlibat di dalamnya. Maka kerjasama pemerintah baik pusat dan daerah sangat diperlukan, mengingat bahwa sekarang di Indonesia berlaku Otonomi Daerah. Pada tahapan ini, pemerintah daerah dapat terlibat aktif di dalam pengelolaan perbatasan.

Bagi Indonesia hal ini akan langsung bersinergi dengan kebijakan pemerintah Indonesia sekarang yang mencoba mengubah paradigma yang pada masa dahulu menganggap bahwa daerah perbatasan adalah halaman belakang dan menangani permasalahan perbatasan melalui pendekatan keamanan (security approach), menjadi paradigma baru yaitu daerah perbatasan adalah halaman muka negara yang harus dikelola dan ditampilkan sebaik mungkin dengan menonjolkan pendekatan kesejahteraan (prosperity approach).

Tidak ada lagi alasan bagi pemerintah setempat dan pemerintah negara yang bersangkutan untuk mengabaikan pembangunan di wilayah tersebut, karena pemerintah "terikat" untuk mengembangkan wilayah dalam kerangka kerjasama kedua negara.

\section{KESIMPULAN}

Keberadaan garis batas menjadi hal sangat strategis terutama ketika terjadi konflik diantara negara yang berbatasan tersebut.

Secara tidak langsung, terdapat dua pemahaman mengenai wilayah perbatasan, secara formal bagi negara dan informal bagi penduduk perbatasan. Negara menjadikan perbatasan sebagai isolasi interaksi komunitas dan kegiatannya dari komunitas dan kegiatan negara di seberangnya. Di pihak rakyat, nilai 
perbatasan yang sejatinya membatasi mereka, menjadi kabur. Karena kepentingan ekonomi sehari-hari, kegiatan sosial kemasyarakatan dan pemenuhan keperluan hidup adalah prioritas utama mereka.

Kondisi wilayah negara tetangga yang lebih pesat pembangunannya memperkuat kaburnya pemahaman perbatasan di pihak rakyat. Orientasi penduduk akan lebih condong ke wilayah yang lebih berkembang tersebut. Dan, satu negara tidak dapat mencegah fenomena seperti itu.

Sebagai jalan tengah, diutarakan pemanfaatan ruang bersama, dimana kegiatan yang berlangsung di wilayah tersebut diberikan perlakuan khusus. Rakyat masih dapat melakukan aktifitasnya secara normal sebagaimana kehidupan sehari-hari, negara pun "diamankan" kedaulatannya terhadap wilayah yang jelas serta status penduduk didalamnya. Ruang Bersama ini dapat mendorong keseriusan negara untuk mengelola ruang bersama karena alasan kewajiban sebagai wilayah kerjasama. Dengan demikian mendorong pula keseriusan pemerintah pada konsep pendekatan kesejahteraan (prosperity approach).

\section{CATATAN AKHIR}

Namun, perlu dicatat bahwa UU no 9 Tahun 1985 tentang Perikanan, Pasal 2, menetapkan bahwa Wilayah Perikanan Indonesia juga meliputi Zona Ekonomi Eksklusif Indonesia.

2 Misalnya Studi yang dilakukan oleh Depkimpraswil 2002, studi BAPPENAS 2004, dan studi Lemhanas 2004 dan LIPI. Juga dalam Ir. Florianus Nahak, MSi, Pengelolan Wilayah Perbatasan IndonesiaTimor Leste (Pengalaman PemKab Belu), makalah pada Seminar Nasional Pengelolaan Wilayah Perbatasan Dalam Rangka Menjaga Keutuhan Wilayah Negara Kesatuan Republik Indonesia, diselenggarakan oleh Jurusan IImu Hubungan Internasional FISIP Universitas Pembangunan Nasional "Veteran", Yogyakarta, tgl 18 November 2008. Lihat juga pada makalah yang disampaikan pada seminar yang sama oleh: Ganewati Wuryandari, Ph.D, Wilayah Perbatasan RI-Timor Leste: Permasalahan dan Model-model Pengelolaan. Begitu juga dalam Rohmad Supriyadi, MSi, op cit. Dan pada Ir. Suwarno P Raharjo, M.Sc, Problematika di Balik Manfaat yang Besar (Rangkuman Hasil Forum Komunikasi dan Koordinasi Batas Wilayah), dalam O.C. Kaligis \& Associates, Sengketa SipadanLigitan Mengapa Kita Kalah, O.C. Kaligis \& Associates, Jakarta, 2003, hal 166-169. Begitu juga dalam Kompas, Perbatasan: Melongok Pintu Gerbang PNG di Vanimo, 21 Desember 2008, hal 5.

3 Ganewati Wuryandari Ph.D, peneliti P2P-LIPI, Wilayah Perbatasan Rl-Timor Leste: Permasalahan dan Model-model Pengelolaan, makalah pada Seminar Nasional Pengelolaan Wilayah Perbatasan
Dalam Rangka Menjaga Keutuhan Wilayah Negara Kesatuan Republik Indonesia, diselenggarakan oleh Jurusan IImu Hubungan Internasional FISIP Universitas Pembangunan Nasional "Veteran", Yogyakarta, tgl 18 November 2008.

\section{REFERENSI}

Asosiasi Hubungan Internasional Indonesia, Lanskap Baru Politik Internasional, Proceeding Konvensi Nasional I Asosiasi Hubungan Internasional Indonesia, Universitas Muhammadiyah Yogyakarta, 2009

Dino Patti Djalal, The Geopolitics of Indonesia's Maritime Territorial Policy, CSIS, Jakarta, 1996

Direktorat Jenderal Kerjasama ASEAN Departemen Luar negeri Republik Indonesia, Kerjasama ASEAN dalam Menanggulangi Kejahatan Lintas Negara, 2001

Florianus Nahak, Ir, MSi, Pengelolan Wilayah Perbatasan IndonesiaTimor Leste (Pengalaman PemKab Belu), Makalah, Yogyakarta, 18 November 2008

Gatra, Edisi Khusus: Di Laut Kita (Belum) Jaya, No. 08 Tahun XII, Januari 2006

Hasjim Djalal, Indonesia and The Law of The Sea, CSIS, Jakarta, 1995

Mustafa Abubakar, Menata Pulau-pulau Kecil Perbatasan Belajar dari kasus Sipadan, Ligitan dan Sebatik, KOMPAS, cetakan 1, 2006

O.C. Kaligis \& Associates, Sengketa Sipadan-Ligitan Mengapa Kita Kalah, O.C. Kaligis \& Associates, Jakarta, 2003

Rohmad Supriyadi, MSi, Strategi dan Model Pengelolaan Perbatasan, Makalah, Yogyakarta, 18 November 2008

Stephen B Jones, A Handbook for Statesmen, Treaty Editors and Boundary Commissioners, 1945

Tempo, Edisi Khusus 60 Tahun Kemerdekaan: Merawat Indonesia, No. 25/XXXIV/15-21 Agustus 2005

Tulus Warsito, DR, Diplomasi Perbatasan, Monograf, Jurusan IImu Hubungan Intrenasional Fakultas IImu Sosial dan Politik Universitas Muhammadiyah Yogyakarta, 2008

Wahyuni Kartikasari, Hubungan Kerjasama Perbatasan IndonesiaMalaysia Studi Kasus Perbatasan Kalimanatan Barat-Sarawak, Skripsi Jurusan Hubungan Internasional FISIPOL Universitas Gadjahmada, 1997

Wahyuni Kartikasari, Trafficking di Wilayah Perbatasan Kalimantan Barat-Sarawak, Thesis, Program Studi Ilmu Politik Program Pasca Sarjana Universitas Gadjah Mada, 2005 